\title{
Antioxidant and Antimicrobial Properties of Pumpkin (Cucurbita maxima) Peel, Flesh and Seeds Powders
}

\author{
Ashiq Hussain $^{1 *} \quad$ Dr. Tusneem Kausar ${ }^{1} \quad$ Dr Ahmad Din $^{2} \quad$ Dr Anjum Murtaza ${ }^{1}$ \\ Muhammad Abdullah Jamil ${ }^{1} \quad$ Saima Noreen $^{1} \quad$ Muhammad Azhar Iqbal ${ }^{1}$ \\ 1.Institute of food science and Nutrition, University of Sargodha, Sargodha, Pakistan \\ 2.National Institute of Food Science and Technology, University of Agriculture Faisalabad, Faisalabad, Pakistan
}

\begin{abstract}
This research work was designed to investigate and utilize all three parts (peel, flesh and seeds) of pumpkin for their antioxidant and antimicrobial activities. Pumpkin parts were separated, dried, grinded to powder and extracted by using $80 \%$ methanol. Percentage yield of pumpkin peel, flesh and seeds extracts, was found $12.37 \pm 0.10,8.84 \pm 0.07$ and $3.53 \pm 0.06 \%$ respectively. DPPH free radical scavenging activity (mg AAE $/ 100 \mathrm{~g}$ ) of pumpkin peel, flesh and seeds extracts was found 13.00 $\pm 0.08,10.58: 0.06$ and 16.53 \pm 0.09 respectively. All three types of extracts exhibited prominent antifungal activities against four fungal strains Candida albicans, Fusarium oxysporum, Mucor miehei and Trichoderma spp. Pumpkin seeds extracts exhibited greater zone of inhibition against these fungal strains as compared to pumpkin peel and flesh extracts. For antibacterial study four bacterial strains Salmonella typhi, Escherichia coli, Bacillus subtilis and Streptococcus aureus were used. Pumpkin flesh extracts exhibited greater antibacterial activities as compared to pumpkin peel and seeds extracts.
\end{abstract}

Keywords: Pumpkin, Extracts, Antibacterial, Antifungal, Zone of inhibition, Free radicals

DOI: $10.7176 / \mathrm{JBAH} / 11-6-05$

Publication date:March $31^{\text {st }} 2021$

\section{INTRODUCTION}

Plants are natural sources of many components, responsible to cure various kinds of diseases. In the modern lifestyle, use of synthetic drugs has gained importance but their adverse effects are always present on human beings. The role of plants, especially fruits and vegetables are highly recognized towards good health and reduced risk of diseases (Mala and Kurian, 2016). Waste generated by fruits and vegetables processing industries is an excellent source of bioactive compounds, which can be directly extracted or transformed into high value-added products (Rico et al., 2020). Antioxidants play a very important role in different ways, during different types of chronic diseases, in the body of living by protecting the cells from oxidation and scavenging the free radicals produced in the body (Skandrani et al., 2010). Antioxidants inhibit the oxidizing chain reactions in the living body. Antioxidants can be natural or synthetic. Synthetic antioxidants are restricted to be used because of their carcinogenic effects (Velioglu et al., 1998). Some important synthetic antioxidants are butylated hydroxytoluene, butylated hydroxy anisole and tertiary butylhydroquinone, which are used for the preservation of fats and oils. But now research provided evidences of adverse effects of these synthetic antioxidants (Yesilyurt et al., 2008). Therefore, interest of scientists in natural antioxidants has grown up because of their beneficial health effects. Fruits and vegetables are believed to have protective mechanism due to presence of phenolic antioxidants. Polyphenols present in fruits, vegetables and herbs and also in products made from these plant materials like cocoa, wines and beverages, are important naturally occurring antioxidants (Aouidi et al., 2011). In the last few years phenolic compounds from natural plant-based materials have attracted the attention of researchers because they play important role in human health by protecting the body tissues from oxidative stress (Chiou et al., 2007).

Pumpkins are classified under the family "Cucurbitaceae" On the basis of stem shape and texture, pumpkins are grouped into Cucurbita maxima, Cucurbita pepo, Cucurbita mixta and Cucurbita moschata (Xanthopoulou et al., 2009). Pumpkin is a versatile vegetable having identical position among all vegetables, due to its peel, flesh and seeds, each possessing outstanding phytochemicals applicable in treatment and prevention of medical disorders (Sharma et al., 2020). Pumpkin different parts are rich source of biologically active compounds like phenolics, flavonoids, flavones, tocopherols and tocotrienols (Asif et al., 2017). Pumpkin flour exhibits high total antioxidant activity (Que et al., 2008). Pretreatment of pumpkin slices by blanching followed by pulsed vacuum osmotic dehydration and then connective drying results in good quality pumpkin flour (Junqueira et al., 2017). Kvapil et al. (2020) analyzed that osmotic dehydration and proper packaging improved the quality of dried pumpkin. Pumpkin seed kernel (PSK) flour can be considered as a potential source of important nutrients for food enrichment due to its high protein (31.96\%), oil (49.87\%), oleic (44.78\%), and linoleic acid (39.40\%) content (Ozturk and Turhan, 2020). Pumpkin peel and seeds are good sources of bioactive compounds which can be extracted maximally by adopting latest technologies (Massa et al., 2019). Bochnak and Swieca (2020) reported that pumpkin powder is good source of potentially bio accessible phenolics and antioxidant capacities. Jukic et al. (2019) reported that flour obtained from pumpkin seed oil press cake can be successfully used as a functional and nutritionally valuable food ingredient. 
According to different studies, pumpkin acts as hypertensive due to its antioxidant activities (Schiffrin, 2010). Antioxidant activity of various extracts of pumpkin fruits could play an important role in individuals with vascular injury, diabetics and pre-diabetics as these extracts of pumpkin fruits will protect cellular damage. Xia and Wang (2006) conducted their research on streptozotocin-induced diabetic animals to demonstrate the antidiabetic as well as antioxidative effect of pumpkin fruit extract. They observed the cell protecting action of pumpkin fruits extract. Vitamin E (tocopherol) which is an antioxidant is found in high contents in pumpkin seeds and pumpkin seeds oil which contains substantial amount of vitamin $\mathrm{E}$ is a good part of Japanese diets (Tokudome et al., 1999). Aquasmethanol (80\%) extracts of pumpkin (Cucurbita maxima), exhibits appreciable antioxidant activities (Kulczynski et al., 2020)

Pumpkin is a potential crop of generating income and overcoming food insecurity. However, spoilage of horticultural produce results due to microbial attack. Microbial spoilage is the major factor limiting shelf-life of fresh produce and processed products. Preservation of pumpkin by drying is best way to prevent microbial spoilage (Kiharason and Isutsa, 2019). Bacteria, viruses, fungi and other parasites causes diseases in humans and due to these diseases, death, disability, social and economic problems for millions of people took place. Although safe and effective medicines are available for treatment of such diseases but still a number of individuals lack safe, healthy and economic access to prevent and treat these diseases. Pathogenic micro-organisms have developed resistance towards drugs which is a sign of alarm for the scientists to develop new more effective drugs for these infectious micro-organisms. That is why natural sources are considered best option to create new formulations and to isolate new anti-microbial components. Pumpkin has provided various broad spectrum anti-microbial components to the researchers. Pumpkin oil inhibits Staphylococcus aureus, Acinetobacter baumanii, Aeromonas veronii, Escherichia coli, Salmonella enterica, Enterococcus faecalis, Pseudomonas aeruginosa, bio group Sorbia, Candida albicans, Klebsiella pneumoniae and Serratia marcescens at the concentration of $2.0 \%$ (v/v) (Hammer et al., 1999). The extracted substances from pumpkin exhibited antimicrobial activity against both gram-positive and gram-negative bacteria (Tadee et al., 2020). Extracts from different parts of pumpkin, contain biologically active components, which show antidiabetic, antibacterial, hypocholesterolemic, antioxidant, anticancer, antimutagenic, immunomodulatory and other miscellaneous effects (Krimer-Malesevic, 2020). Alabassi et al. (2020) demonstrated that pumpkin fruit is a powerful antibacterial and antioxidant agent. Various parts of pumpkin plants contain various antibiotic components including antibacterial and antifungal agents. Some of these agents are proteins such as $\alpha$ and $\beta$-moschins, myeloid antimicrobial peptide (Ng et al., 2002; Xiong, 2000; Vassiliou et al., 1998). Recently a new protein named as Pr-1 was isolated from pumpkin by Park et al. (2010) which exhibits strong antifungal effect without any harmful or toxic effect on human erythrocytes. This protein is quite stable towards high temperature up to $70{ }^{\circ} \mathrm{C}$. Skin, seeds and leaves of pumpkin possess antioxidant and antibacterial constituents (Dissanayake et al., 2018). Pumpkin seed oil showed remarkable antioxidant and antibacterial activities (Amin et al., 2020). Phyto-therapy is being used to discover new herbal medicines but only a few herbal plants have got importance to cure diseases. It is very important to test the herbal plant and its therapeutic agents scientifically by experiments and to validate their results before their commercial use as a number of plants have toxic agents with their side effects (Yadav et al., 2010).

The objectives of the present research work were to investigate all three parts (peel, flesh and seeds) of pumpkins cultivated in subcontinent, for their antioxidant and antimicrobial potential, in order to utilize the waste streams of pumpkin fruits, as good source of functional and medicinal ingredients, during their consumption and processing.

\section{MATERIAL AND METHODS}

\section{Collection of raw materials and chemicals}

Mature pumpkins ( $\mathrm{n}=40)$ with an average weight of $5 \pm 0.5 \mathrm{~kg}$, were collected from the local market of district Sargodha, Pakistan. Specimen was submitted in Department of Botany, University of Sargodha for identification. All the chemicals used in this research work were of reagent grade purchased from Sigma-Aldrich chemicals. Bacterial and fungal strains were obtained from department of Biotechnology, University of Sargodha.

\section{Preparation of pumpkin peel, flesh and seeds powders}

Pumpkins were washed with fresh running water and then with distilled water to remove any foreign material attached and separation of three fractions (peel, flesh and seeds) was done manually with the help of knife. These three parts, were cleaned properly from fibrous material attached and placed in stainless steel containers under sunlight for a time period of 48 hours. Pumpkin fractions were dried through conventional hot air-drying method. Powder of each of these three fractions was obtained firstly by drying the pumpkin parts in hot air oven (BIOBASE HAS-T105 China) at $60^{\circ} \mathrm{C}$ till constant weight and secondly by grinding of dried parts with grinder (NIMA NM8300 Japan), as described by Pongjanta et al. (2006). Resulting final powders were stored at ambient conditions in polyethylene bags. 


\section{Preparation of pumpkin peel, flesh and seeds powder's extracts}

Extracts of three types of pumpkin powders were prepared by following the procedure given by Asif et al. (2017). According to these guidelines, 20 gm of powders (peel, flesh and seeds) sample was taken and $80 \%$ methanol was used as solvent for each type of extract. Twenty grams of each sample powder was soaked in solvent (200 ml) and continuous stirring was done at $200 \mathrm{rpm}$ in orbital shaker (Biosan ES-20 Japan), for a time period of $120 \mathrm{~h}$ at $25^{\circ} \mathrm{C}$. Separation of this mixture was done with the help of Whatman filter paper. Concentration of this filtrate was done through vacuum rotary evaporator (BIOLAND RE-5000A China). Five ml raw 80\% methanolic $(80 \% \mathrm{MeOH})$ extract of each fraction was stored for further analysis at $4{ }^{\circ} \mathrm{C}$ temperature. Yield of extraction was measured through following equation in terms of percentage:

$$
\text { Yield }(\%)=\frac{\text { Solvent free extract weight }(g)}{\text { Weight of dried extract }(g)} \times 100
$$

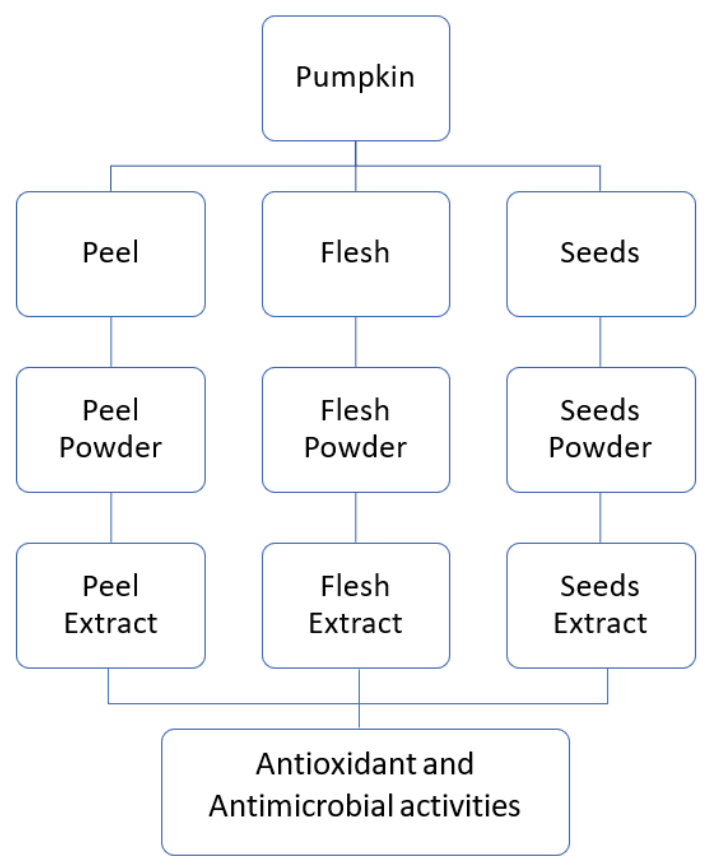

\section{Figure 1. Overview of research work plan}

\section{Determination of antioxidant activity by DPPH free radical scavenging Method}

Free radical scavenging activity of pumpkin (peel, flesh and seeds) powders was analyzed through DPPH assay as illustrated by Brand-Williams et al. (1995), with slight modifications. An amount of $0.01 \mathrm{~g}$ of 2,2-diphenyl-1picrylhydrazyl (DPPH) was taken after weighing and transferred into a $25-\mathrm{mL}$ volumetric flask having solvent (80:20 methanol/water (v/v). Flask was filled with solvent, up to the marking level. A calibration curve for ascorbic acid was also developed. An amount of $100 \mu \mathrm{l}$ from each type of $80 \% \mathrm{MeOH}$ extract was collected in microplates, then an amount of $2.0 \mathrm{ml}$ solvent and $250 \mu \mathrm{l}$ DPPH reagent were added. These microplates were shaken and kept in darkness at ambient temperature for a time period of 20 mint. Reduction in DPPH absorbance by spectrophotometer (Hitachi U-2900 Japan) at $520 \mathrm{~nm}$ was witnessed every 5 min intervals unless this absorbance was stabilized after a time period of 30 mints. Methanol played its role as blank solution, while DPPH solution with no test samples acted as control. All samples analyses were done in triplicate. The DPPH radical scavenging activity of pumpkin powder's methanolic extracts was shown as mg of ascorbic acid equivalent (AAE) /100 g powder in a reaction time of 30 mints.

Antimicrobial activities of pumpkin peel, flesh and seeds powders

Pumpkin peel, flesh and seeds powder's $80 \% \mathrm{MeOH}$ extracts were used to study their antimicrobial activity against bacterial and fungal strains.

Antifungal Activity of pumpkin peel, flesh and seeds powders

Agar well diffusion method was used to determine the antifungal activity of pumpkin peel, flesh and seeds extracts as described by Khaing, (2011), with little modifications. Firstly, fungal growth of four strains was taken in a 
water-bath shaker in their respective broths at $25-30^{\circ} \mathrm{C}$ for 48 hours. Harvesting of strains, after incubation, was done and fugal suspensions $(100 \mu \mathrm{l})$ were taken through swab on a certain media called SDA (Sabouraud ${ }^{\text {ee }} \mathrm{s}$ Dextrose Agar). On agar plates equally spaced wells were produced through punching out agar and after that these were heavily seeded with test organisms. These extracts were dissolved in methanol, filled in the wells and Diflozon was used as control. After filling, inoculation of plates was done for 24 hours at $37^{\circ} \mathrm{C}$ and measured zones of inhibition in millimeter by following the guidelines given by APHA (2001).

\section{Antibacterial activity of pumpkin peel, flesh and seeds powders}

Antibacterial activity of pumpkin peel, flesh and seeds powder's extracts was determined by disc diffusion technique as described by Marinova et al. (2005), with slight modifications. Test bacteria like gram positive i.e., Staphylococcus aureus, Bacillus subtilus and gram negative i.e., Salmonella typhi, Escherichia coli were inoculated over the nutrient agar medium with help of sterile cotton buds. $80 \% \mathrm{MeOH}$ extracts of pumpkin peel, flesh and seeds were used to determine antibacterial activity. These extracts were planted with the help of discs, at organisms-inoculated plates at identical distances and similarly, the control drug Ciprofloxacin. The incubation of bacterial planted dishes was carried out for 24 hours at $37^{\circ} \mathrm{C}$. The diameter of inhibition zones was determined in mm as per guidelines given by APHA (2001).

\section{RESULTS AND DISCUSSION}

\section{Preparation of pumpkin peel, flesh and seeds powder's extracts}

The values of percentage yield of $80 \% \mathrm{MeOH}$ extracts of pumpkin peel, flesh and seeds powders has been presented in Table 1, from where it was clear that among peel, flesh and seeds, highest percentage of extract yield was found for pumpkin peel powder and lowest percentage of extract yield was found for pumpkin seeds powder. Extracts of pumpkin peel, flesh and seeds were prepared using most friendly and effectively working solvents i.e., Methanol and water in 80:20 ratio due to the reason that all volatile and non-volatile components get extracted by two types of solvents mixture. Higher yield of extracts of pumpkin flesh and peel might be due to more active components present because these are places of more metabolism (Asif et al., 2017). Asif et al. (2017) conducted research to investigate antioxidant potential of 65, 80 and $99.9 \%$ methanolic extracts of pumpkin peel and puree and results for percentage yield of extracts were; Pumpkin peel extract 65\% MeOH (15.61\%), 80\% MeOH (16.23\%) and $99.9 \mathrm{MeOH}(18.45 \%)$ whereas, pumpkin puree extract $65 \% \mathrm{MeOH}(10.52 \%), 80 \% \mathrm{MeOH}(12.41 \%)$ and 99.9 $\mathrm{MeOH}(14.10 \%)$. From these results it was clear that yield of extracts was greater from peel fraction as compared to puree and by decreasing the concentration of methanol yield of extracts was reduced for both peel and puree. Wanna, (2019) gave results for ethanolic extracts yield (\%) for pumpkin peel and flesh as $4.29 \%$ and $6.78 \%$ respectively. Singh et al. (2016) extracted different parts of Cucurbit fruits with different solvents and gave results for pumpkin peel and pulp 70\% methanolic extracts as $7.37 \%$ and $5.43 \%$ respectively. Jarungjitaree and Naradisorn (2019) evaluated pumpkin peel by using different types of solvents and also their different concentrations and gave results for yield of pumpkin peel extracts of $95 \%, 70 \%$ and $50 \%$ methanol extracts as $14.05,15.75$ and $20.00 \%$ respectively. These results were in close resemblance with our research work. Xanthopoulou et al. (2009) used four different types of solvents to extract four different types of pumpkin seeds groups and determined their yield as $\mathrm{g}$ of extract per $100 \mathrm{~g}$ of pumpkin seeds. Methanol extracts of four groups of pumpkin seeds resulted extracts yield range 1.54-3.4 g/100 g.

Table 1: Percentage of extracts yield of pumpkin peel, flesh and seeds powders

\begin{tabular}{cc}
\hline Pumpkin powders & Extract's yield (\%) \\
\hline Peel powder & $12.37 \pm 0.10 \mathrm{a}$ \\
Flesh powder & $8.84 \pm 0.07 \mathrm{~b}$ \\
Seed's powder & $3.53 \pm 0.06 \mathrm{c}$ \\
\hline
\end{tabular}

Means sharing similar letter in a column are statistically non-significant and means sharing different letter in a column are statistically significant $(\mathrm{P}>0.05)$.

\section{Determination of Antioxidant Activity with the DPPH Radical Scavenging Method}

Data of DPPH free radical scavenging activity of $80 \% \mathrm{MeOH}$ extracts of pumpkin peel, flesh and seeds powders has been presented in Table 2. Significantly different values of DPPH free radical scavenging activity of each type of extract were obtained. Among three types of extracts, greater DPPH free radical scavenging activity was exhibited by pumpkin seeds extract and lower DPPH free radical scavenging activity was found from pumpkin flesh extract.

Phenolic compounds such as alkaloids, saponins, flavonoids and steroids present in pumpkin fruits parts especially seeds and pulp have been found good antioxidant agents ((Mala and Kurian, 2016)). Asif et al. (2017) conducted research to investigate antioxidant activity of $65 \%, 80 \%$ and $99.9 \%$ methanolic extracts of pumpkin peel and puree by using DPPH free radical scavenging assay and declared that pumpkin peel and puree extract $(99.9 \% \mathrm{MeOH})$ exhibited promising antioxidant activity $68.79 \%$ and $69.56 \%$ respectively. They also concluded 
that by decreasing the concentration of methanol antioxidant activity was reduced. Dissanayake et al. (2018) determined the antioxidant activities of three fractions skin, seeds and leaves of Sri Lankan variety of pumpkin by using three different types of solvents through DPPH free radial method and concluded leaves presented greater antioxidant activity as compared to seeds and skin while skin showed greater antioxidant activity as compared to seeds. Acetone extracts gave least values and ethyl acetate extracts higher values for antioxidant activity whereas methanol extracts values were in between of both these. Tyan et al. (2018) determined antioxidant activity of three plants extracts of Cucurbitaceae family by using DPPH free radical scavenging assay and concluded that all the extracts showed an increase in antioxidant activity by increasing the concentration of dose. They suggested that pumpkins could reduce the diseases related towards oxidation of lipids such as cardiovascular diseases. Singh et al. (2016) extracted different parts of Cucurbit fruits with different solvents to determine their antioxidant activity by DPPH free radical scavenging method and values of antioxidant activity for $70 \%$ methanolic extract of pumpkin peel and pulp were $43.79 \%$ and $38.56 \%$ respectively.

Table 2: DPPH free radical scavenging activity of pumpkin peel, flesh and seeds powders

\begin{tabular}{cc}
\hline Pumpkin powders & DPPH free radical scavenging activity (mg AAE /100 g) \\
\hline Peel powder & $13.00 \pm 0.08 \mathrm{~b}$ \\
Flesh powder & $10.58 \pm 0.06 \mathrm{c}$ \\
Seed's powder & $16.53 \pm 0.09 \mathrm{a}$ \\
\hline
\end{tabular}

Means sharing similar letter in a column are statistically non-significant and means sharing different letter in a column are statistically significant $(\mathrm{P}>0.05)$.

\section{Antifungal Activity of pumpkin peel, flesh and seeds powders}

Results of antifungal activities of pumpkin peel, flesh and seeds $80 \% \mathrm{MeOH}$ extracts against four fungal species have been presented in Table 3. Antifungal activity of $80 \% \mathrm{MeOH}$ extract of pumpkin peel was significantly different against four fungal species. Highest zone of inhibition $8.69 \pm 0.10 \mathrm{~mm}$ against Candida albicans and lowest zone of inhibition $3.11 \pm 0.05 \mathrm{~mm}$ was observed against Trichoderma spp. Similarly, antifungal activity of $80 \% \mathrm{MeOH}$ extract of pumpkin flesh was significantly different against these fungal species. Highest zone of inhibition $7.80 \pm 0.08 \mathrm{~mm}$ against Candida albicans and lowest zone of inhibition $3.38 \pm 0.07 \mathrm{~mm}$ was observed against Trichoderma spp. Similar trend was also observed when pumpkin seeds $80 \% \mathrm{MeOH}$ were used against these fungal species as highest zone of inhibition $9.34 \pm 0.06 \mathrm{~mm}$ against Candida albicans and lowest zone of inhibition $6.24 \pm 0.02 \mathrm{~mm}$ was observed against Trichoderma spp. Standard drug used in this study Diflozon exhibited zone of inhibition $8.52 \pm 0.04 \mathrm{~mm}$ against Candida albicans, $2.23 \pm 0.04 \mathrm{~mm}$ against Trichoderma spp., $5.33 \pm 0.06 \mathrm{~mm}$ against Mucor miehei and $4.33 \pm 0.05 \mathrm{~mm}$ against Fusarium oxysporum.

Now when we compared antifungal activities of these three types of extracts against individual species one by one, significantly different values were obtained, as pumpkin seeds extract exhibited highest zone of inhibition against Candida albicans, pumpkin peel extract zone of inhibition was in between flesh and seeds and pumpkin flesh exhibited lowest zone of inhibition. Similarly, significant data was obtained against Mucor miehei as highest zone of inhibition was exhibited by pumpkin seeds extract, lower zone of inhibition by pumpkin peel extract and lowest zone of inhibition by pumpkin flesh extract. Data was also significant for antifungal activities of these three types of extracts against Trichoderma spp. Where also pumpkin seeds extract exhibited highest zone of inhibition but lowest zone of inhibition was observed by pumpkin peel extracts and intermediate zone of inhibition was observed by pumpkin flesh extracts. When antifungal activity against Fusarium oxysporum for pumpkin peel, flesh and seeds extracts was compared significant different values were obtained for each type of extracts. From these results it was also clear that higher antifungal activities were observed by pumpkin seeds extracts when compared with pumpkin peel and flesh extracts.

Although pumpkin contains less protein contents (less than $2.0 \%$ of dry matter weight) but there are very essential amino acids and proteins in pumpkin parts which acts as antifungal agents (Zhang, 2003). Phenolic compounds especially alkaloids and flavonoids present in fruits are found useful antimicrobial and antiinflammatory agents (Waterman, 1992). Abd El-Aziz and Abd El-Kalek, (2011) extracted different proteins from pumpkin (Cucurbita moschata) peel, pulp and seeds and tested for their antifungal effect. Extracted crude proteins from pumpkin seeds exhibited zone of inhibition against Candida albicans $5.0 \mathrm{~mm}$, against Rhodotorula rubra $9.0 \mathrm{~mm}$, against Aspergillus flavus (A) $10.0 \mathrm{~mm}$, against Penicillium chrysogenum $1.0 \mathrm{~mm}$ and against Rhizopus spp. $1.0 \mathrm{~mm}$. Whereas no zone of inhibition was noticed against Aspergillus niger, Aspergillus flavus (H), Trichoderma viride, Aspergillus fumigates and Aspergillus parasiticus. On the other hand, extracted crude proteins from pumpkin rind exhibited zone of inhibition against Candida albicans $4.0 \mathrm{~mm}$, against Rhodotorula rubra 6.0 mm, against Aspergillus flavus (A) $25.0 \mathrm{~mm}$, against Penicillium chrysogenum $27.5 \mathrm{~mm}$, against Rhizopus spp. $2.0 \mathrm{~mm}$, against Aspergillus niger $5.0 \mathrm{~mm}$, against Aspergillus flavus (H) $4.0 \mathrm{~mm}$, against Trichoderma viride 4.0 $\mathrm{mm}$ and against Aspergillus fumigates $23.0 \mathrm{~mm}$ while no zone of inhibition was examined against Aspergillus parasiticus. Extracted crude proteins from pumpkin pulp exhibited zone of inhibition against Rhodotorula rubra $8.0 \mathrm{~mm}$, against Aspergillus flavus (A) $4.0 \mathrm{~mm}$, against Aspergillus niger $4.5 \mathrm{~mm}$ and against Rhizopus spp. 1.0 
mm. Yadav et al. (2013) gave a list of antifungal proteins with their molecular weights isolated from different parts of pumpkin. PR-1 having molecular weight 40 was isolated from pumpkins rind and PR-2 having molecular weight 14.8 was also isolated from pumpkins rind and these proteins possess antifungal activity against different fungal species. PR-5 having molecular weight 28 was isolated from pumpkins leaves and exhibit antifungal activity against Candida albicans. Cucurmoschin having molecular weight 8 was isolated from pumpkins seeds and exhibit antifungal activity against Fusarium oxysporum, Mycosphaerella oxysporum and Botrytis cinereal.

Another study by Pandey et al. (2010) proved that pumpkin seeds oils are good antifungal agents. Volatile constituents from essential oils of Cucurbita maxima seeds were tested against 3 fungal strains and was found growth inhibition (\%) against Aspergillus niger 51.2\%, against Aspergillus flavus $46.2 \%$ and against Candida albicans $41.1 \%$. Kabbashi et al. (2014) conducted in vitro study to prove antifungal effects of Cucurbita maxima seeds ethanolic extracts against two standard fungal strains. At a concentration of $12.5 \mathrm{mg} / \mathrm{ml}$ pumpkin seeds ethanolic extracts exhibited zone of inhibition $15 \mathrm{~mm}$ against Candida albicans and $16 \mathrm{~mm}$ against Aspergillus niger. Further they found increased zone of inhibition by increasing the amount of extract concentration. They also tested standard antifungal drugs Nystatin and Clotrimazole as standard.

Badar et al. (2011) determined the chemical composition and biological activity of ripe pumpkin fruit parts and found that pumpkin seed oil exhibited strong antifungal activities against fungal specie Saccharomyces cerevisiae. Zone of inhibition against fungal strain Mucor miehi was $16 \mathrm{~mm}$ from pumpkin flesh extract and $15 \mathrm{~mm}$ from pumpkin rind extract.

Table 3: Antifungal activity of pumpkin peel, flesh and seeds powders

\begin{tabular}{cccccc}
\hline \multirow{2}{*}{$\begin{array}{c}\text { Extracts (80\% } \\
\text { MeOH) }\end{array}$} & $\begin{array}{c}\text { Fusarium } \\
\text { oxysporum }\end{array}$ & $\begin{array}{c}\text { Trichoderma } \\
\text { spp. }\end{array}$ & Mucor miehei & $\begin{array}{c}\text { Candida } \\
\text { albicans }\end{array}$ & $\begin{array}{l}\text { Overall } \\
\text { Means }\end{array}$ \\
\cline { 2 - 5 } & $5.07 \pm 0.06 \mathrm{~h}$ & $3.11 \pm 0.05 \mathrm{k}$ & $6.13 \pm 0.05 \mathrm{e}$ & $8.69 \pm 0.10 \mathrm{~b}$ & $5.75 \pm 0.61 \mathrm{~b}$ \\
Pumpkin peel extract & $5.72 \pm 0.05 \mathrm{f}$ & $3.38 \pm 0.07 \mathrm{j}$ & $5.13 \pm 0.09 \mathrm{~h}$ & $7.80 \pm 0.08 \mathrm{c}$ & $5.51 \pm 0.48 \mathrm{c}$ \\
Pumpkin flesh extract & $7.80 \pm 0.06 \mathrm{c}$ & $6.24 \pm 0.02 \mathrm{e}$ & $6.57 \pm 0.09 \mathrm{~d}$ & $9.34 \pm 0.06 \mathrm{a}$ & $7.49 \pm 0.37 \mathrm{a}$ \\
Pumpkin seeds extract & $4.33 \pm 0.05 \mathrm{i}$ & $2.23 \pm 0.041$ & $5.33 \pm 0.06 \mathrm{~g}$ & $8.52 \pm 0.04 \mathrm{~b}$ & $5.10 \pm 0.68 \mathrm{~d}$ \\
Reference (Diflozon) & $5.73 \pm 0.39 \mathrm{~B}$ & $3.74 \pm 0.45 \mathrm{C}$ & $5.79 \pm 0.18 \mathrm{~B}$ & $8.59 \pm 0.17 \mathrm{~A}$ & \\
\hline Overall Means &
\end{tabular}

Means sharing similar letter in a row or in a column are statistically non-significant and means sharing different letter in a column are statistically significant $(\mathrm{P}>0.05)$. Small letters represent comparison among interaction means and capital letters are used for overall mean.

\section{Antibacterial activity of pumpkin peel, flesh and seeds powders}

Data of antibacterial activities of three types of pumpkin powders $80 \% \mathrm{MeOH}$ extracts against four bacterial species has been presented in Table 4. Significantly different values were obtained for antibacterial activity of pumpkin peel, flesh and seeds extracts against four bacterial species. Against bacterial specie Salmonella typhi, all three types of extracts, exhibited significant antibacterial activity, very comparable to standard antibacterial drug used. Against bacterial species Escherichia coli and Bacillus subtilis pumpkin flesh extract exhibited greater zone of inhibition as compared to peel and seeds extracts. Against bacterial specie Streptococcus aureus pumpkin peel, flesh and seeds extracts exhibited non-significant activity whereas, standard drug Ciprofloxacin exhibited significant inhibition.

In plant leaves and different parts of fruits phenolic compounds are present especially alkaloids and flavonoids which have been reported as useful antimicrobial agents (Waterman, 1992). Phytochemicals such as saponins, tannins, flavonoids, alkaloids and steroids present in pumpkin fruit parts might have been playing their role as antibacterial agents (Chonoko and Rufai 2011). Asif et al. (2017) conducted research to investigate antibacterial activity of $65 \%, 80 \%$ and $99.9 \%$ methanolic extracts of pumpkin peel and puree against four bacterial strains E. coli, P. multocida, S. aureus and B. subtilis. Zone of inhibition of pumpkin peel and puree methanolic extracts against P. multocida was greater than $15 \mathrm{~mm}$ whereas against other three bacterial strains zone of inhibition was in the range of 10 to $15 \mathrm{~mm}$. Dissanayake et al. (2018) used three bacterial strains S. aureus, B. subtilis and E. coli to determine the antibacterial activity of pumpkin skin, seeds and leaves extracts by using three types of solvents; acetone, methanol and ethyl acetate. Methanol extract of pumpkin skin gave zone of inhibition of $7.58 \mathrm{~mm}$ against S. aureus and $4.83 \mathrm{~mm}$ against B. subtilis whereas no zone of inhibition was observed against E. coli. On the other hand, methanolic extracts of pumpkin seeds gave no results as antimicrobial agent but ethyl acetate extract of pumpkin seeds showed $6.61 \mathrm{~mm}$ inhibition zone against S. aureus. Jun et al. (2006) extracted pectic polysaccharides from pumpkin peel and studied their growth promoting effect on good intestinal bacteria L. brevis, B. bifidum and B. longum and growth retarding effect on bad intestinal bacteria E. coli and C. perfringens. Tyan et al. (2018) tested seven bacterial strains to check the antimicrobial activity of pumpkins extracts and found that Cucurbita moschata extracts showed antimicrobial activity against all bacterial strains. Chonoko and Rufai (2011) conducted research on phytochemical screening and antimicrobial activity of pumpkin and reported an inhibition zone in the range of 7-10 mm of both ethanolic and methanolic extracts of pumpkin peel against bacterial 
specie S. aureus and 6-12 mm range of zone of inhibition against S. typhi. Badar et al. (2011) determined the chemical composition and biological activity of ripe pumpkin fruit parts and found that pumpkin rind and flesh extracts exhibited moderate antimicrobial activities against Gram positive bacteria B. subtilis and B. cereus. Both pumpkin rind and flesh extracts showed a zone of inhibition $17 \mathrm{~mm}$ against bacterial strain $\mathrm{S}$. viridochromogenes.

Antibacterial activity of pumpkin extracts is related to antibacterial proteins from pumpkin parts and seed oils from pumpkin seeds (Caili et al., 2006). Phenolic compounds present in fruits and vegetables are strongly responsible for antibacterial activity as discussed in previous reports that polar isopropyl functionality of phenolic components may involve in bacteriostatic activities (Farag et al., 1989). Antibacterial actions of phenolic compounds have been associated with reaction of these compounds with cellular components resulting in leakage of nucleotides and proteinaceous material into extracellular areas (Degre and Sylvestre 1983).

Table 4: Antibacterial activity of pumpkin peel, flesh and seeds powders

\begin{tabular}{|c|c|c|c|c|c|}
\hline \multirow[b]{2}{*}{ Extracts $(80 \% \mathrm{MeOH})$} & \multicolumn{4}{|c|}{ Zone of inhibition (mm) } & \multirow{2}{*}{$\begin{array}{l}\text { Overall } \\
\text { Means }\end{array}$} \\
\hline & $\begin{array}{c}\text { Streptococcus } \\
\text { aureus }\end{array}$ & $\begin{array}{l}\text { Bacillus } \\
\text { subtilis }\end{array}$ & $\begin{array}{c}\text { Escherichia } \\
\text { coli }\end{array}$ & $\begin{array}{c}\text { Salmonella } \\
\text { typhi }\end{array}$ & \\
\hline Pumpkin peel extract & $6.60 \pm 0.26 \mathrm{f}$ & $4.43 \pm 0.13 \mathrm{~g}$ & $7.03 \pm 0.23 \mathrm{ef}$ & $13.41 \pm 0.21 \mathrm{c}$ & $7.87 \pm 1.01 \mathrm{~b}$ \\
\hline Pumpkin flesh extract & $6.67 \pm 0.41 \mathrm{f}$ & $6.40 \pm 0.26 \mathrm{f}$ & $8.63 \pm 0.20 \mathrm{~d}$ & $15.18 \pm 0.09 \mathrm{a}$ & $9.22 \pm 1.08 \mathrm{a}$ \\
\hline Pumpkin seeds extract & $6.43 \pm 0.23 f$ & $3.70 \pm 0.15 \mathrm{~h}$ & $5.07 \pm 0.27 \mathrm{~g}$ & $14.40 \pm 0.19 b$ & $7.40 \pm 1.26 \mathrm{c}$ \\
\hline $\begin{array}{c}\text { Reference } \\
\text { (Ciprofloxacin) }\end{array}$ & $7.60 \pm 0.26 \mathrm{e}$ & $3.00 \pm 0.17 \mathrm{i}$ & $6.43 \pm 0.18 \mathrm{f}$ & $14.97 \pm 0.05 \mathrm{ab}$ & $8.00 \pm 1.32 \mathrm{~b}$ \\
\hline Overall Means & $6.83 \pm 0.19 \mathrm{~B}$ & $4.38 \pm 0.39 \mathrm{C}$ & $6.79 \pm 0.40 \mathrm{~B}$ & $14.49 \pm 0.22 \mathrm{~A}$ & \\
\hline
\end{tabular}

Means sharing similar letter in a row or in a column are statistically non-significant and means sharing different letter in a row or column are statistically significant $(\mathrm{P}>0.05)$. Small letters represent comparison among interaction means and capital letters are used for overall mean.

\section{CONCLUSION}

Pumpkin is one of the important, nutritious and medicinal vegetables, which has been consumed from ancient times to cure different remedies. In subcontinent pumpkin is cooked as vegetable and during preparatory operations of pumpkin, peel and seeds are discarded as waste material, but these seeds and peel are good source of phytochemicals responsible for antioxidant and antimicrobial activities to play important role in the field of medicine. Extracts from pumpkin constituents' parts when tested, exhibited remarkable antioxidant and antimicrobial activities.

\section{RECOMMENDATIONS}

Pumpkin peel, flesh and seeds can be converted into powders and extracts which become more concentrated source of nutrients and can be utilized in medicines and novel food products. Phytochemicals and proteins present in pumpkin constituent parts can be extracted to develop safe and novel antioxidant and antimicrobial drugs. After approval from scientific community pumpkin based nutraceuticals and cosmetics can be commercially marketed for the well-being of humans.

\section{ACKNOWLEDGEMENTS}

The authors would like to thank Department of Chemistry and Department of Microbiology, University of Sargodha, Pakistan, for facilitating this research work by providing resources. Special thanks to faculty members of IFSN, University of Sargodha, Pakistan, for writing assistance of this manuscript.

\section{CONFLICT OF INTEREST}

All authors declared that they have no conflict of interest.

\section{FUNDING}

No funds were availed for this research work.

\section{REFERENCES}

A. P. H. A. (2001). Frances, PD and Keith, I. (Eds.), Compendium of Methods for the Microbiological Examination of Foods. Washington, $D C$

Abd EI-Aziz, A. B., \& Abd EI-Kalek, H. H. (2011). Antimicrobial proteins and oil seeds from pumpkin (Cucurbita moschata). Nature and Science, 9(3), 105-119.

Alabassi, H. M., Kadri, Z. H. M., Gathwan, M. A., Kadem, Y. J., \& Kadhim, Z. K. (2020). Therapeutic Effect of Pumpkin (Cucurbita pepo L.) on Post Burn Injury in White Mice. Systematic Reviews in Pharmacy, 11(4), 616-620.

Amin, M. Z., Rity, T. I., Uddin, M. R., Rahman, M. M., \& Uddin, M. J. (2020). A comparative assessment of anti- 
inflammatory, anti-oxidant and anti-bacterial activities of hybrid and indigenous varieties of pumpkin (Cucurbita maxima Linn.) seed oil. Biocatalysis and Agricultural Biotechnology, 28, 101767.

Aouidi, F., Ayari, S., Ferhi, H., Roussos, S., \& Hamdi, M. (2011). Gamma irradiation of air-dried olive leaves: Effective decontamination and impact on the antioxidative properties and on phenolic compounds. Food chemistry, 127(3), 1105-1113.

Asif, M., Raza Naqvi, S. A., Sherazi, T. A., Ahmad, M., Zahoor, A. F., Shahzad, S. A., ... \& Mahmood, N. (2017). Antioxidant, antibacterial and antiproliferative activities of pumpkin (cucurbit) peel and puree extracts-an in vitro study. Pakistan journal of pharmaceutical sciences, 30(4), 1327-1334.

Badr, S. E., Shaaban, M., Elkholy, Y. M., Helal, M. H., Hamza, A. S., Masoud, M. S., \& El Safty, M. M. (2011). Chemical composition and biological activity of ripe pumpkin fruits (Cucurbita pepo L.) cultivated in Egyptian habitats. Natural product research, 25(16), 1524-1539.

Bochnak, J., \& Świeca, M. (2020). Potentially bioaccessible phenolics, antioxidant capacities and the colour of carrot, pumpkin and apple powders-effect of drying temperature and sample structure. International Journal of Food Science \& Technology, 55(1), 136-145.

Brand-Williams, W., Cuvelier, M. E., \& Berset, C. L. W. T. (1995). Use of a free radical method to evaluate antioxidant activity. LWT-Food science and Technology, 28(1), 25-30.

Caili, F. U., Huan, S., \& Quanhong, L. I. (2006). A review on pharmacological activities and utilization technologies of pumpkin. Plant foods for human nutrition, 61(2), 70-77.

Chiou, A., Karathanos, V. T., Mylona, A., Salta, F. N., Preventi, F., \& Andrikopoulos, N. K. (2007). Currants (Vitis vinifera L.) content of simple phenolics and antioxidant activity. Food Chemistry, 102(2), 516-522.

Chonoko, U. G., \& Rufai, A. B. (2011). Phytochemical screening and antibacterial activity of Cucurbita pepo (Pumpkin) against Staphylococcus aureus and Salmonella typhi. Bayero Journal of Pure and Applied Sciences, 4(1), 145-147.

Degre, R., \& Sylvestre, M. (1983). Effect of butylated hydroxy anisole on the cytoplasmic membrane of Staphylococcus aureus Wood 46. Journal of food protection, 46(3), 206-209.

Dissanayake, D. M. R. H., Deraniyagala, S. A., Hettiarachchi, C. M., \& Thiripuranathar, G. (2018). The study of antioxidant and antibacterial properties of skin, seeds and leaves of the Sri Lankan variety of pumpkin. IOSR journal of pharmacy, 8(2), 43-48.

Farag, R. S., Daw, Z. Y., \& Abo - Raya, S. H. (1989). Influence of some spice essential oils on Aspergillus parasiticus growth and production of aflatoxins in a synthetic medium. Journal of food science, 54(1), 74-76.

Hammer, K. A., Carson, C. F., \& Riley, T. V. (1999). Antimicrobial activity of essential oils and other plant extracts. Journal of applied microbiology, 86(6), 985-990.

Jarungjitaree, P., \& Naradisorn, M. (2019). Evaluation of antioxidant and antifungal activities of pumpkin byproduct and its application in banana. Journal of Food Science and Agricultural Technology (JFAT), 4, 129133.

Jukić, M., Lukinac, J., Čuljak, J., Pavlović, M., Šubarić, D., \& Koceva Komlenić, D. (2019). Quality evaluation of biscuits produced from composite blends of pumpkin seed oil press cake and wheat flour. International journal of food science \& technology, 54(3), 602-609.

Jun, H. I., Lee, C. H., Song, G. S., \& Kim, Y. S. (2006). Characterization of the pectic polysaccharides from pumpkin peel. LWT-Food Science and Technology, 39(5), 554-561.

Junqueira, J. R. D. J., Corrêa, J. L. G., \& Ernesto, D. B. (2017). Microwave, convective, and intermittent microwave-convective drying of pulsed vacuum osmo-dehydrated pumpkin slices. Journal of Food Processing and Preservation, 41(6), e13250.

Kabbashi, A. S., Koko, W. S., Mohammed, S. E. A., Musa, N., Osman, E. E., Dahab, M. M., ... \& Mohammed, A. K. (2014). In vitro amoebicidal, antimicrobial and antioxidant activities of the plants Adansonia digitata and Cucurbit maxima. Advancement in Medicinal Plant Research, 2(3), 50-57.

Khaing, T. A. (2011). Evaluation of the antifungal and antioxidant activities of the leaf extract of Aloe vera (Aloe barbadensis Miller). World Academy of Science, Engineering and Technology, 75, 610-612.

Kiharason, J. W., \& Isutsa, D. K. (2019). Shelf-life of pumpkin fruit slices, flour and blended products. International Journal of Food Science and Biotechnology, 4(1), 14.

Krimer-Malesevic, V. (2020). Pumpkin Seeds: Phenolic Acids in Pumpkin Seed (Cucurbita pepo L.). In Nuts and Seeds in Health and Disease Prevention (pp. 533-542). Academic Press.

Kulczyński, B., Gramza-Michałowska, A., \& Królczyk, J. B. (2020). Optimization of extraction conditions for the antioxidant potential of different pumpkin varieties (Cucurbita maxima). Sustainability, 12(4), 1305.

Kvapil, M. F., Rodríguez, S. D. C., Qüesta, A. G., \& Mascheroni, R. H. (2020). Evaluation of process conditions on osmotic dehydration and quality indexes of pumpkin (Cucurbita moschata) and further polymeric film selection for packaging and refrigerated storage. International Journal of Food Science \& Technology. https://ifst.onlinelibrary.wiley.com/doi/abs/10.1111/ijfs.14827

Mala, K. S., \& Kurian, A. E. (2016). Nutritional composition and antioxidant activity of pumpkin 
wastes. International Journal of Pharmaceutical, Chemical \& Biological Sciences, 6(3), 336-344.

Marinova, D., Ribarova, F., \& Atanassova, M. (2005). Total phenolics and total flavonoids in Bulgarian fruits and vegetables. Journal of the university of chemical technology and metallurgy, 40(3), 255-260.

Massa, T. B., Stevanato, N., Cardozo - Filho, L., \& da Silva, C. (2019). Pumpkin (Cucurbita maxima) by products: Obtaining seed oil enriched with active compounds from the peel by ultrasonic - assisted extraction. Journal of Food Process Engineering, 42(5), e13125.

Ng, T. B., Parkash, A., \& Tso, W. W. (2002). Purification and characterization of moschins, arginine-glutamaterich proteins with translation-inhibiting activity from brown pumpkin (Cucurbita moschata) seeds. Protein expression and purification, 26(1), 9-13.

Ozturk, T., \& Turhan, S. (2020). Physicochemical properties of pumpkin (Cucurbita pepo L.) seed kernel flour and its utilization in beef meatballs as a fat replacer and functional ingredient. Journal of Food Processing and Preservation, 44(9), e14695.

Pandey, R. R., Dubey, R. C., \& Saini, S. (2010). Phytochemical and antimicrobial studies on essential oils of some aromatic plants. African Journal of Biotechnology, 9(28), 4364-4368.

Park, S. C., Lee, J. R., Kim, J. Y., Hwang, I., Nah, J. W., Cheong, H., ... \& Hahm, K. S. (2010). Pr-1, a novel antifungal protein from pumpkin rinds. Biotechnology letters, 32(1), 125.

Pongjanta, J., Naulbunrang, A., Kawngdang, S., Manon, T., \& Thepjaikat, T. (2006). Utilization of pumpkin powder in bakery products. Songklanakarin Journal of Science and Technology, 28(1), 71-79.

Popeseu, S., Bordei, D., \& Georgescu, D. (1972). Antistaling agents in bread making. Indian Aliment, 23, 547550.

Que, F., Mao, L., Fang, X., \& Wu, T. (2008). Comparison of hot air - drying and freeze - drying on the physicochemical properties and antioxidant activities of pumpkin (Cucurbita moschata Duch.) flours. International journal of food science \& technology, 43(7), 1195-1201.

Rico, X., Gullón, B., Alonso, J. L., \& Yáñez, R. (2020). Recovery of high value-added compounds from pineapple, melon, watermelon and pumpkin processing by-products: An overview. Food Research International, 132, 109086.

Schiffrin, E. L. (2010). Antioxidants in hypertension and cardiovascular disease. Molecular interventions, 10(6), 354.

Sharma, P., Kaur, G., Kehinde, B. A., Chhikara, N., Panghal, A., \& Kaur, H. (2020). Pharmacological and biomedical uses of extracts of pumpkin and its relatives and applications in the food industry: a review. International Journal of Vegetable Science, 26(1), 79-95.

Singh, J., Singh, V., Shukla, S., \& Rai, A. K. (2016). Phenolic content and antioxidant capacity of selected cucurbit fruits extracted with different solvents. J Nutr Food Sci, 6(565), 2.

Skandrani, I., Limem, I., Neffati, A., Boubaker, J., Sghaier, M. B., Bhouri, W., ... \& Chekir-Ghedira, L. (2010). Assessment of phenolic content, free-radical-scavenging capacity genotoxic and anti-genotoxic effect of aqueous extract prepared from Moricandia arvensis leaves. Food and chemical toxicology, 48(2), 710-715.

Tadee, P., Chukiatsiri, K., Amornlerdpisan, D., Paserakung, A., \& Kittiwan, N. (2020). Antimicrobial effect of Japanese pumpkin (Cucurbita maxima) extract on local mastitis pathogen. Veterinary Integrative Sciences, 18(3), 141-152.

Tokudome, Y., Imaeda, N., Ikeda, M., Kitagawa, I., Fujiwara, N., \& Tokudome, S. (1999). Foods contributing to absolute intake and variance in intake of fat, fatty acids and cholesterol in middle-aged Japanese. Journal of epidemiology, 9(2), 78-90.

Tyan, C. Y., Radhakrishnan, L., Mustaffa, F., \& Sahgal, G. (2018). Antioxidant, antimicrobial and SPF protective activity of Cucurbita moschata, Cucurbita reticulata and Clitoria ternatea. Reports De Pharmacie. 4, 488491

Vassiliou, A. G., Neumann, G. M., Condron, R., \& Polya, G. M. (1998). Purification and mass spectrometryassisted sequencing of basic antifungal proteins from seeds of pumpkin (Cucurbita maxima). Plant Science, 134(2), 141-162.

Velioglu, Y. S., Mazza, G., Gao, L., \& Oomah, B. D. (1998). Antioxidant activity and total phenolics in selected fruits, vegetables, and grain products. Journal of agricultural and food chemistry, 46(10), 4113-4117.

Wanna, C. (2019). Free Radical Scavenging Capacity and Total Phenolic Contents in Peel and Fleshy Crude Extracts of Selected Vegetables. Pharmacognosy Journal, 11(6).

Waterman, P. G. (1990). Searching for bioactive compounds: various strategies. Journal of Natural Products, 53(1), 13-22.

Xanthopoulou, M. N., Nomikos, T., Fragopoulou, E., \& Antonopoulou, S. (2009). Antioxidant and lipoxygenase inhibitory activities of pumpkin seed extracts. Food Research International, 42(5-6), 641-646.

Xanthopoulou, M. N., Nomikos, T., Fragopoulou, E., \& Antonopoulou, S. (2009). Antioxidant and lipoxygenase inhibitory activities of pumpkin seed extracts. Food Research International, 42(5-6), 641-646. 
Xia, T., \& Wang, Q. (2006). D - chiro - Inositol found in Cucurbita ficifolia (Cucurbitaceae) fruit extracts plays the hypoglycaemic role in streptozocin - diabetic rats. Journal of pharmacy and pharmacology, 58(11), 1527-1532.

Xiong, X. M. (2000). Study on extraction and separation of effective composition of pumpkin polysaccharide and its glucatonic effect. Chinese Traditional Patent Medicine, 22(8), 563-565.

Yadav, S., Tomar, A. K., Yadav, R. N., \& Yadav, S. (2013). Screening of antifungal proteins from plants of Cucurbitaceae family against Fusarium oxysporum: potential as bio fungicides. International Research Journal of Environmental Science, 2(6), 91-96.

Yeşilyurt, V., Halfon, B., Öztürk, M., \& Topçu, G. (2008). Antioxidant potential and phenolic constituents of Salvia cedronella. Food chemistry, 108(1), 31-39.

Zhang, H. (2003). Determination of $\gamma$-amino-butyric acid and amino acids in pumpkin. Food Research Development, 24(3), 108-109.

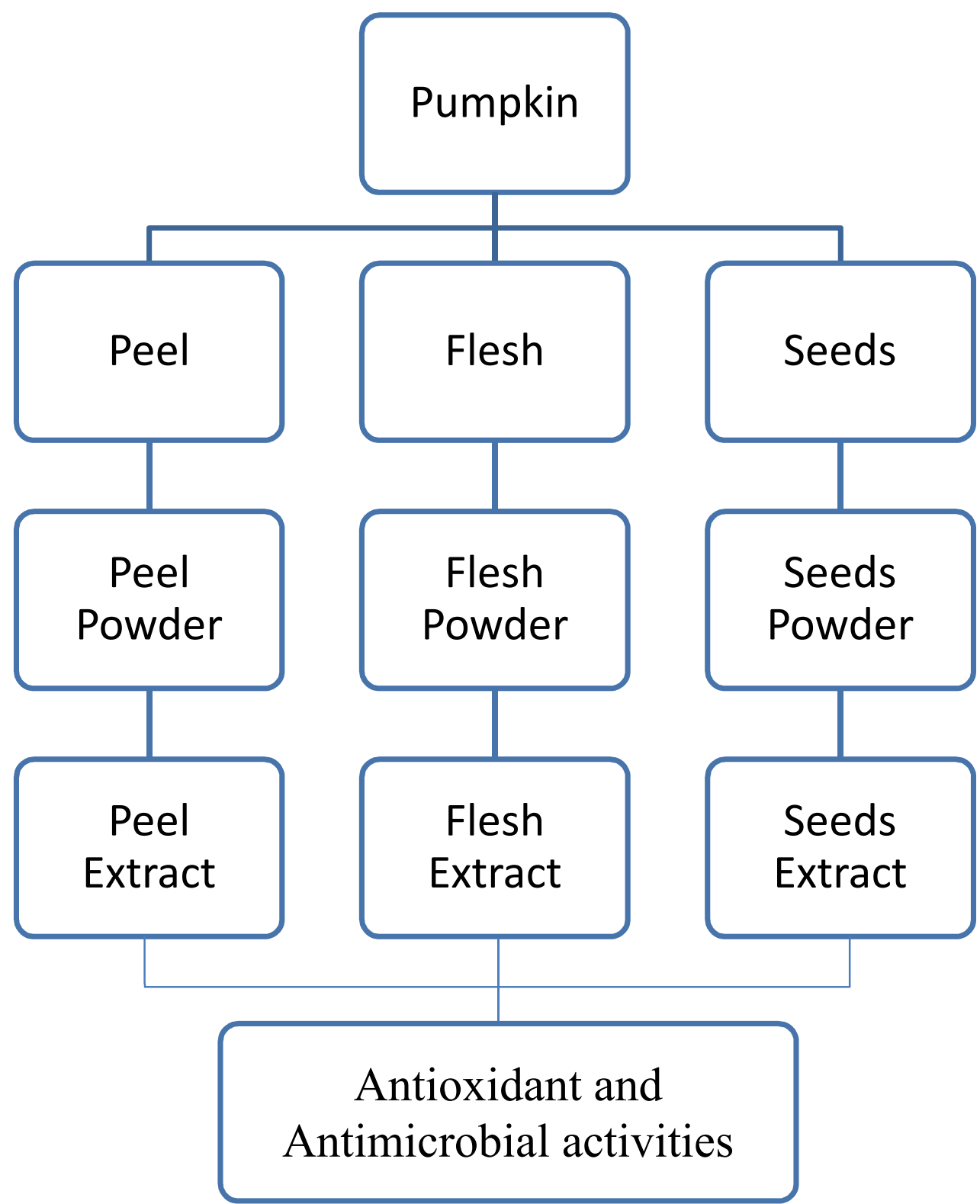

